\title{
A Comparative Analysis of Religious Education in Europe and Educational Guidelines in the Framework of Interreligious dialogue and a Culture of Peace
}

\author{
Dr. Luis Del Espino Díaz
}

University of Cordoba, Spain

Doi: $10.2478 / \mathrm{mjss}-2018-0004$

\begin{abstract}
The phenomenon of migration that typifies a globalized world has created a society characterized by cultural and religious diversity. This has led to different types of conflict. States cannot disregard the current situation, and so intercultural strategies that encourage interreligious dialogue aimed at building a culture of peace must be part of educational curricula. This article analyses the religious education implemented in most European states so that using this material as a starting point, educational guidelines and strategies can be developed to make religious education into a subject that can contribute to the welfare of all human beings in a globalized world, valuing cultural diversity and social equality.
\end{abstract}

Keywords: Religious Education, Interreligious Dialogue, Interculturality, Culture of Peace, Inclusive Education

\section{Introduction}

One of the typical features of twenty-first century society is its religious and cultural diversity, partly deriving from the phenomenon of migration (García and Martínez, 2016). This situation has become a source of small-scale social and civic conflicts (as in the case of the use of the different types of veil worn by Muslim women in certain public spaces) and more severe ones like armed conflicts as Álvarez, González, and Fernández (2012) note (for example, the breakup of the former Yugoslavia).

The starting point for this study is the fact that the cultural and religious diversity in our society that is typical of a globalized world means that it is necessary to acquire a series of civic skills to help develop a culture of peace. A culture of peace is understood as a culture in which individuals, groups, and nations have cooperative and productive relationships with each other and where the conflicts that inevitably arise are handled constructively (Alzate, 2013).

García and Martínez $(2016,175)$, citing Bloch, define religion as:

A form that appears at a given point in history in response to certain needs in the process of human development. They are forms, vessels that hold the human being's spirituality, its deep ability to grasp dimensions beyond the immediate reality surrounding it or its particular needs and interests as a person and a people. We believe that all religions can find common ground in searching for this spirituality or mysticism and making it apparent. At the same time, each religion can specialize and complement the others, as none of them is 'the one true faith', none of them has a monopoly on human spirituality.

Taking this definition into account, we might add that it is impossible to understand a civilization without first understanding its religion (Enterria, 2006), its worldview, and the role of the human being in it (Martínez, 2016). For this reason, the development of interreligious education in 
the framework of intercultural education can play an important role in creating spaces for convergence between human groups from different creeds and cultures. According to Torradeflot (2011), interreligious dialogue can become one of the most useful instruments for transforming situations of conflict as religious traditions can enable their followers to overcome particular interests in order to achieve a greater collective good. According to this author, when interreligious dialogue is close (local or neighbourhood-based), it can help prevent and resolve interreligious conflicts, enriching processes of public involvement and creating the conditions that enable solidarity and justice (Vila, 2015).

Religious education is fully established in the different curricula across Europe. However, our starting position is that neither teaching of religion nor teaching about religion can escape from the implications of the cultural and religious pluralism that characterizes the cosmopolitan social settings in which most of humankind nowadays goes through life (Fernández, González, and Álvarez, 2014). Consequently, it is necessary to include curriculum elements in religious education that favour the development of interreligious dialogue and so become a tool for intercultural mediation. To this end, we will review the international state of affairs in the area of religious freedom and intercultural and interreligious dialogue.

The main aim of this article, therefore, is to analyse religious education curricula in Europe in order to infer subsequently how it is possible to move forwards from them towards knowledge and recognition of cultural diversity and interreligious dialogue to encourage a culture of peace.

\section{Methodology}

The methodology adopted for our paper is that of a bibliographic review on the subject matter, that is, Religious education in Europe and interreligious dialogue within the framework of a culture of peace. Therefore, it is a qualitative approach study.

The selection criteria carried out to obtain the data by the consulted sources have been diverse. With regard to the data referring to Religious diversity in Europe: Size and distribution, the data published in two sources has been consulted mainly. First, Eurydice, which supports and facilitates European cooperation in the field of lifelong learning, by providing information on educational systems and policies in 38 countries and by producing studies on issues common to European education systems. In this case, the data are provided by the governments of the respective countries from the censuses they periodically carry out.

On the other hand, the second major source from which the data from our study come is Pew Research Center. The projections in this report are based on the best sources of reference data that were available for each country and territory at the time of the research. The researchers considered many sources to determine the size of the religious groups in each country in the reference year and the factors that would influence the projected changes in the size of those groups, including age and sexual composition, fertility rates, patterns of migration and religious change. Pew Forum researchers acquired and analyzed religious composition information from about, data sources, including censuses, demographic surveys, general population surveys and other studies - the largest project of its kind to date. Censuses were the primary source for Pew Forum religious composition estimates in countries, which together cover of all people in the world.

\section{Religious Diversity in Europe: Size and Distribution ${ }^{1}$}

Until recently, as García and Martínez (2016) note, Europe was a homogenous continent in its race (white), culture (Western), and religion (Christianity). Nowadays, we find a wide range of ethnicities, cultures, and religions, principally as a result of the spread of globalization, that has so often been analysed.

\footnotetext{
${ }^{1}$ These data on the religious demographics of countries have been derived from two information sources: Eurydice, a European Commission information source about education whose numbers are provided by governments; and the Pew Research Center's Forum on Religion \& Public Life (2012). Both sources may be consulted online: http://eacea.ec.europa.eu/education/eurydice/eurypedia_en.php and http://www.pewforum.org/
} 
Before carrying out a more extensive investigation into the religious education in Europe and other countries, we will review the size and distribution of the European population according to its religion, taking as a basis a report carried out by Pew Research Center's Forum on Religion \& Public Life (2011), a demographic study carried out in more than 200 countries, showed that a quarter of all Christians of the whole world (26\%) live in Europe, taking into account the 50 European countries which the Research focused on. This is the reason why Europe is the continent with the second highest number of Christians in the world, after America. Russia has the largest number of Christians in Europe (105 million), which entails around 19\% of European Christians and near $5 \%$ globally. The ten European countries with the greatest number of Christians comprise $20 \%$ of all Christians in the world. On the other hand, in recent decades, the Muslim share of the population throughout Europe grew about 1 percentage point a decade, from $4 \%$ in 1990 to $6 \%$ in 2010 (Pew Research Center, 2016).

In terms of Christian denominations, the cited report continues, Catholics are the largest Christian group in Europe, representing almost five out of ten European Christians (46\%). Secondly, the Orthodox denomination forms 35\% of European Christians. The majority of Orthodox Christians around the world (76\%) live in Europe. Even though the Protestant reform began in Europe, nowadays less than one of five European Christians (18\%) fit in the Protestant Tradition.

From now on, our analysis will focus especially on the religious education in the educational system of the countries analyzed the type of relevant institution in the drafting of the curricula and on the administrative status of teachers of this subject. Then, we will suggest some teaching guidelines in order to include intercultural elements in religious education curricula within a framework of interreligious dialogue.

\section{Religious Education in European Educational Systems ${ }^{2}$}

Regarding religious education in Europe, Álvarez and Essomba (2012) outline the models of religious education according to three factors: responsibility (religious communities, government agencies, or a shared responsibility between religious communities and State), voluntariness or compulsoriness to receive the formation on the part of students and the denominational character (with a State religion or not). Carrying on with this bibliographic reference about education and interreligious dialogue coordinated by professor Álvarez, it is emphasized that, in reference to the denominational character, three models of religious education are recognised in the European context:

- Mono-denominational state, in which, only the official State religion is taught (in Europe, fundamentally, the Catholic, Lutheran and Orthodox affiliations of Christianity).

- Pluri-denominational state, in which, each religious community, regardless of its numbers, has access to the public school to teach to their own faithful in separate classes.

- Secular State, in which religious education is not allowed and, in many cases, is replaced by classes on civic responsibility or on education of values (Dietz, 2008).

Álvarez and Essomba (2012) highlight that in Europe we can find three models of religious education according to factors of religious content, the teachers and the way it is presented in the curricula:

- Denominational teaching of religion, in which the religious institution is in charge of the subject.

- Non-denominational religious teaching, in which the teachers expand on different religions.

- Trans-curricular teaching of religious content, in which there is no specific religious subject, in this case religion is dealt with transversally.

\subsection{Catholic Majority Countries}

In Germany, Religion classes run for two or three hours per week. The legal basis is found in the 1949 and 1990 Constitutions (after the unification), just like the Agreements of Churches with the

\footnotetext{
${ }^{2}$ These data on Religious Education in Europe have been derived from Del Espino-Díaz (2017).
} 
Länder. This is a compulsory subject with the option to a possible dispensation. According to the Länder, the alternative subject can include philosophical, ethical, values and study contents. The teachers of religion are considered public workers just like the rest of the teachers.

The case of Austria, the religious education workload is two hours per week in both, primary and secondary school. The legal framework that supports the subject is the 1998 and 1995 Constitutions, together with the agreements with the Church and education laws. The subject is a free choice for students and its alternative is made up of study activities without academic value. The status of the teachers of religion is as an acting official.

In Belgium, Religious education has two hours per week both in primary and secondary schools. The legal framework can be found in the Constitution and the 1959 school pact. The subject is compulsory or optional free choice for the students. The alternative subject to religion is based on non- confessional and civic ethics. The status of the teachers of religion is as an acting official.

On the other hand, in Croatia, the religious formation is based on the state laws and on the agreements with the different religious communities. The subject is a free choice for the students and its alternative subject is Ethics. The teacher of religion has the same status as the rest of the teachers.

The case of Slovakia the legal basis of religious education is the agreements with the different churches. The subject is a free choice for the students and its alternative subject is Ethics. The teachers of religion have the same work conditions and status as the rest of the teachers.

The situation in France, regarding religious education, is different from the other countries in Europe due to the lay tradition of the country (Massignon, 2011). However, in recent years, a national debate about this type of education has been generated. Firstly, in the area of education, the French teachers need to admit the crisis of the humanities -that together with the Greek and Roman classic culture and with the literary culture is included the religious facet and in general terms, there is an impoverished transmission of such culture. Secondly, in the purely religious sphere, there is seen to be the signs of a crisis of the traditional means of religious transmission (a lessening of religious practices, a decrease in the number of students in catechism classes, a crisis in the religious transmission in the family) which indicates an important lack of religious culture in the French population. These two crises together are responsible for the religious ignorance that we see in the new generations (Estivalèzes, 2008). However, on $19^{\text {th }}$ February 2005, and as a suggestion coming from the communist member, Jean-Pierre Brard, the French National Assembly approved a motion to teach religion in the state schools. It is important to highlight that in the public centres of the department of Haut-Rhin and Lower Rhine (old Alsace) and in Mosela (Lorraine) Religion appears in the curricula and school timetable. The teacher is usually a priest or a pastoral agent for secondary schools.

In Netherlands, the religious education is based on the Constitution, on the Law for Basic Education and on the so called Mammoth Law. It is studied in all public and private school for three hours a week. The school hours are distributed between lessons and worship. The subject is a free choice for parents in the public schools and it is compulsory in denominational schools. The alternative subject is Philosophy. The teacher is designated by the religious authorities and their professional status is the same as the rest of the teachers.

In the Irish case, the religious teaching is based on the 1973 Constitution and on the Agreements with the Church. This subject is taught in all schools, regardless their private or public ownership, for 92 hours in each stage of Primary Education. In Secondary Education, the school has the freedom to set a timetable with two or three hours per week. This is a free-choice subject for the students.

In Italy, the academic status of the subject of religion is based on the Italian Constitution and the Agreements with the Holy See signed in 1984. This subject is taught in all public and private schools, with a workload of two hours per week in Primary Education and one hour per week in Secondary Education. The alternative is a subject or an activity decided by the school. The teachers of religion have the same academic and professional status as the other teachers and they are appointed by the appropriate religious authority.

In Lithuania, the Agreements with the Roman Catholic Church are the legal basis for the 
religious education. It is a free choice subject for students and its alternative is Ethics. The workload is either one or two hours per week. The teachers are proposed by the religious authorities and their status is similar to the rest of the teachers.

In Luxembourg, the religious teaching has its legal basis on the 1868 Constitution, revised in 1994. It has a workload of one hour per week in Primary Education. It is a compulsory subject, except at the request of a dispensation asked by the parents, in which case the students must attend an alternative subject: Ethics and Civic Education. The teachers are priests or catechists with over three years of Theology and they have the same professional status as the other teachers.

In Malta, the Agreements with the Roman Catholic Church are the legal basis of the religious education. It is a compulsory subject with a possible dispensation. The teachers are proposed by the religious authorities and their professional status is the same as the rest of the teachers.

In Poland, The Laws on Education and the Agreements with the religious communities are the legal basis of the teaching of religion. This is a free-choice subject. The teachers are proposed by the relevant religious authorities and they have the same professional status as the rest of the teachers.

In Portugal, the religious teaching has its legal basis on the Constitution of 1976 and in the Decree of the Moral and Religious teaching of 1998. The subject is compulsory with a possible dispensation. The workload is one hour per week. The Education authorities establish an alternative subject called Personal and Civic Education. The teachers are appointed by the relevant religious authorities and their professional status is the same as the rest of the teachers.

In Czech Republic, their legal bases are the State Laws and the agreements with the religious communities. Religion is a free-choice subject and it is taught by voluntary teachers.

In the Swiss Cantons, the religious teaching is based on the Constitution 1974 that was modified in 2000 by the separation of the Swedish Church and State. Religious education, which is taught two hours per week, is compulsory in all public and private schools, and therefore, it has no alternative subject. The teacher of Religion must comply with the same requirements and enjoys the same professional status as the rest of the teachers in the educational system.

\subsection{Orthodox Majority Countries}

In Greece, Religious education has a workload of one or two hours per week in Primary Schools (it is taught by the usual teaching staff of the school) and two hours in Secondary Schools (the teachers are university graduates in Theology). It is taught both in public and private centres. The subject is legally based on the 1975 Constitution. In this case, the subject is compulsory since third grade (dispensations may be asked for). As it is a compulsory subject there is no other alternative. The Religion teacher is considered a staff member just like the rest of the teachers.

In Romania, The Education Laws are the legal basis of religious education in the school curriculum. The teaching of Religion is compulsory in Primary School and a free-choice subject in Secondary School. The teachers are proposed by the relevant religious authorities and they have the same professional status as the rest of the teachers.

\subsection{Protestant Majority Countries}

In Denmark, the legal basis of its presence in the syllabus is based on the Constitution. The subject is compulsory in all school centres, with a possible dispensation and, given the compulsory character; it has no alternative subject. Its workload is one or two hours per week in Primary Education; in Secondary Education around 76 hours total during the third grade. In Denmark, the teacher of religion has the same work conditions and status as the rest of the teachers.

In Finland, the presence of the subject of Religion in the curriculum is based on the Constitution, on Religious Freedom Act and on the Law for Basic Education. This is a compulsory subject that it is studied both in public and private schools. In High School, it is only taught one hour per week. Religion is a free choice subject for the students and its alternative subject is Ethics. The teacher belongs to the religious denomination corresponding to the religion taught. 
The Case of Latvia, the subject of religion has either one or two hours per week. The legal basis is on the Agreements with different religious communities. It is a free-choice subject for the students; the teachers are proposed by the relevant religious authority and have the same status as the other teachers.

In Norwegian, the education laws of 1997 are the legal basis for the teaching of Religion. The subject is compulsory with a possible dispensation. The teachers are proposed by the relevant religious authorities and they have the same professional status as the rest of the teachers.

In United Kingdom, the legal basis of the teaching of Religion is found in the Education Act of 1944 (that of Scotland dated 1980). The subject is taught in subsidised centers and in those owned by a church. In Northern Ireland, the subject of religion must be offered in all centers, as in Scotland. It is a compulsory subject, but the parents can request a dispensation. As the subject of Religion is compulsory there is no alternative subject to it. The teacher of religion has the same professional status as the other teachers.

In Sweden, the religious teaching is based on the Constitution 1974 that was modified in 2000 by the separation of the Swedish Church and State. Religious education, which is taught two hours per week, is compulsory in all public and private schools, and therefore, it has no alternative subject. The teacher of Religion must comply with the same requirements and enjoys the same professional status as the rest of the teachers in the educational system.

\section{The International Situation regarding Religious Freedom and Identity and Intercultural/Interreligious Dialogue}

As it is of interest for this study, it is important to examine the international situation regarding religious freedom and intercultural and interreligious dialogue. To do so, we will focus on three institutions: The United Nations, UNESCO, and the Council of Europe.

\subsection{The United Nations}

The United Nations has issued numerous resolutions regarding the importance of dialogue among civilizations, the culture of peace, and interreligious dialogue. These include Resolution 56/6 of 9 November 2001 regarding the Global Agenda for Dialogue among Civilizations; Resolution 57/6 of 4 November 2002 regarding the Promotion of a Culture of Peace and Non-Violence; Resolution 58/128 of 19 December 2003 regarding the Promotion of Religious and Cultural Understanding, Harmony and Cooperation; Resolution 59/23 of 11 November 2004 regarding the Promotion of Interreligious Dialogue; Resolution 59/143 of 15 December 2004 regarding the declaration of the decade 2001-2010 as the International Decade for a Culture of Peace and Non-Violence for the Children of the World; Resolution 62/90 of 25 January 2008 regarding the Promotion of interreligious and intercultural dialogue, understanding and cooperation for peace; and The Declaration of 2010 as the International Year for the Rapprochement of Cultures.

There have also been various resolutions on the promotion of interreligious and intercultural dialogue, understanding, and cooperation for peace such as Resolution 61/221 of 20 December 2006; Resolution 63/22 of 16 December 2008; Resolution 64/81 of 7 December 2009; Resolution 65/138 of 5 April 2011; Resolution 67/104 of 17 December 2012. Proclamation of an International Decade for the Rapprochement of Cultures (2013-2022).

\subsection{UNESCO}

On the same lines as the United Nations, UNESCO has issued the following recommendations, reports, and declarations regarding the promotion of dialogue, understanding, and cooperation between religions and cultures in support of peace: the Recommendation concerning Education for International Understanding, Cooperation and Peace and Education relating to Human Rights and Fundamental Freedoms (1974); the Declaration on the Role of Religion in the Promotion of a Culture of Peace (1994); the UNESCO Universal Declaration on Cultural Diversity (2001); the Convention on the Protection and Promotion of the Diversity of Cultural Expressions (2005); the 
UNESCO World Report emphasising the priority of investing in cultural diversity and intercultural dialogue (2009); UNESCO's Interreligious Dialogue Programme. Furthermore, in the 2012-2013 biennial budget the defence of the integration of culture and intercultural dialogue in development policies with the aim of fostering a culture of peace and non-violence was supported as a priority.

\subsection{Council of Europe}

As for the Council of Europe, following various conferences and seminars organized since the 1990s, the Third Summit of the Heads of State or Government of the Council of Europe (Warsaw, May 2005) supported intercultural dialogue along with political and interreligious dialogue in its Action Plan as a means of ensuring that the diversity of European cultures is a source of mutual enrichment. Since then, the promotion of intercultural dialogue has been one of the political priorities of the Council of Europe's Committee of Ministers.

Other Council of Europe initiatives include the Faro Declaration on the Council of Europe's Strategy for Developing Intercultural Dialogue (2005); a project called "The Challenge of Intercultural Education Today: Religious Diversity and Dialogue in Europe" and the work entitled Religious Diversity and Intercultural Education: A Reference Book for Schools (2007) that derived from it; the White Paper on Intercultural Dialogue (2008); and Recommendation CM/Rec(2008)12 of the Committee of Ministers to Member States on the Dimension of Religions and Non-religious Convictions within Intercultural Education. In 2010 the project called "Education and Religious Diversity in the Western Mediterranean" was launched, ending in 2014; Recommendation $\mathrm{CM} / \operatorname{Rec}(2011) 4$ of the Committee of Ministers to Member States on Education for Global Interdependence and Solidarity.

Despite the international state of affairs, we have just described, according to the US Commission on International Religious Freedom (2014) there is a lack of recognition of freedom of conscience and religion with regards to policies and formal practices in many countries around the world. Indeed, the Pew Forum of Religion and Public Life (2014), notes that $76 \%$ of the world's population live in countries with severe legal restrictions on freedom of religion.

For their part, Bloom, Arikan, and Sommer (2014) note the correlation between globalization and the threat to major religions in that there are growing restrictions on religious freedom in the world.

\section{Including Intercultural Guidelines in Religious Education in the Framework of Interreligious Dialogue}

In order to include intercultural elements in religious education curricula within a framework of interreligious dialogue and encourage a culture of peace, taking the international state of affairs, we have just described as a starting point, we suggest the following teaching guidelines or strategies.

Firstly, the cultural and religious diversity to which we allude requires a series of guidelines in the classroom to encourage an intercultural atmosphere and interreligious dialogue as well as the assimilation of civic competences by the general public. These include understanding the opportunities that diversity provides for benefitting society and learning to confront its challenges; it is also necessary to provide elements for analysing the structure of social inequality that has been legitimised based on difference; it is important to encourage critical reflection on intercultural education as a strategy for handling conflict; constructing and applying knowledge through an international network for exchanging intercultural experiences might be of value for understanding cultural diversity; developing attitudes, skills, and competences for intercultural communication including communicating knowledge and arguments so that it can contribute as a whole to creating spaces for and a culture of peace; promoting the use of technology as a tool for encouraging exchange; boosting the development of skills for independent and cooperative learning; religious education should also include strategies that help with identifying and selecting suitable responses to the challenges of varied and changing contexts; one interesting idea is to provide students with knowledge of the different policies, programmes, and projects being implemented from an intercultural perspective; encouraging the resolution of complex problems from the intercultural 
perspective; work in classrooms aimed at identifying the elements and processes that legitimate social inequality; and promoting processes that contribute to equity and social participation.

Alongside the guidelines identified above, and in the area of the values and attitudes listed, it is necessary to promote social attitudes, behaviour, and changes that reject cultural discrimination and develop positive relationships between cultures: arranging intercultural programmes; transmitting positive messages in favour of multicultural coexistence and diversity; publicising the distinctive cultural values of immigrants and their contributions to the host society; improving their social and emotional integration and their self-concept; applying a pedagogy of recognition; favouring coexistence and preventing and solving intercultural conflicts, among other measures (García, Martínez, and Sahuquillo, 2012).

For their part, García and Martínez (2016) propose a line of action in intercultural education as a tool for interreligious dialogue based firstly on the task of recognizing the stereotypes and misconceptions people might have about religious traditions, as well as establishing the shared elements that facilitate dialogue between different religious traditions and cultures; knowledge of one's own religious traditions to identify interpretations that can prevent situations of conflict while building social cohesion that are consistent with the scenario provided by human rights; developing paths for coming together, critical and realistic debate from mutual respect and seminars, conferences, workshops that articulate a free and constructive interreligious dialogue; and incorporating teaching materials based on the main religions and the elements that unite them. On the other hand, it is also necessary to create interreligious education workshops aimed at the teachers of all levels of school education.

Similarly, and on the same lines as the doctrine of the United Nations, it is vital to strengthen dialogue as a special tool for preventing conflicts and mediating in them, focussing it on promoting respect, understanding, and intercultural and interreligious tolerance.

\section{Conclusion}

As it has just been shown, the teaching of religion is present, in one way or another according to the idiosyncrasy of each country, in all of the analysed euro-zone countries. A wide range of studies (Del Espino-Díaz, 2017) show the importance of the presence of religious teaching in the curricula. This is essential for the Development of a culture of Peace so necessary in the current society with its multicultural character.

Moreover, there is a recent research (Fernández, González and Álvarez, 2014) which advocates for the development of an inter-cultural education in the context of a Civic Education and a Culture of Peace. From the perspective of cultural diversity and social equality, this will contribute to social well-being in a globalised world. The cosmopolitan nature of the societies in which most of the European population now live entails both cultural and religious pluralism. This in turn assumes the concepts of freedom of thought, ideology and conscience to be necessary. Religious education needs to consider and reflect these factors. In fact, Cultural diversity includes the religious diversity of a Society and, by extension, the world. Starting from this premise, it is necessary to develop a dialogical pedagogy capable of opening Intercultural educational innovation that can be optimized in students' knowledge and appreciation of religious pluralism in civil society (Santos, 2017).

Because of the reasons above, it is important to foster the research on inter-cultural education. This has several potentialities, among which we find the possibility of carrying out a more realistic analysis of multi-culturalism and of the actions designed and implemented in this type of areas of diversity (Castillo, 2008). Likewise, this study will contribute to increase the efficacy of the new action strategies in this field, in a particular way the teachers' training in inter-cultural abilities. To that end, it is necessary to promote a dialogue between cultures that fills the empty space between them. According to Sennett (2012), the dialectic achieves a process of exchange that facilitates mutual understanding (Tamayo, 2013). Similarly, Tamayo and Fornet-Betancourt (2005) argue that inter-cultural dialogue must be dialogical but not dialectical. On the other hand, prior to the establishment of intercultural spaces it is imperative to start from democratic contexts that support the right to religious freedom (Julian, 2000). This facilitates the discovery of shared values. 


\section{References}

Álvarez, J. L. (2008). La investigación en educación intercultural. Revista Ciencias de la Educación, 215, 263278.

Álvarez, José Luis and Essomba, M. A. (2012). Dioses en las aulas. Educación y diálogo interreligioso. Barcelona: Graó

Álvarez, J.L., González, H. and Fernández. G. (2012). El conflicto cultural y religioso. Aproximación etiológica. In J. L. Álvarez and M. A. Essomba (Eds.), Dioses en las aulas. Educación y diálogo interreligioso, (p. 2360). Barcelona: Graó).

Alzate Saez, R. (2013). Desarrollo de la cultura de la paz y la convivencia en el ámbito municipal: La mediación comunitaria. Política y Sociedad 50(1): 179-195.

Ben-Nun Bloom, P., Gizen A., and Udi S. (2014). Globalization, Threat and Religious Freedom. Political Studies $62,273-291$.

Del Espino-Díaz, L. (2017). Sociedad, Cultura y Religión: Hacia una Educación Inclusiva en un contexto Intercultural. Córdoba: Diputación de Córdoba

Dietz, G. (2008). La educación religiosa en España: ¿Contribución al diálogo intercultural o factor de conflicto entre religiones? Estudios sobre las Culturas Contemporáneas, 14 (28), 11-46.

Enterría, Á. (2006). La India por dentro. Una guía cultural para el viajero. Varanasi: Indica Books.

Essomba, M. A. (2012). Implicaciones organizativas y de la diversidad religiosa y de creencias en la escuela. Principios, valores y temas clave. In J. L. Álvarez and M. A. Essomba (Eds.), Dioses en las aulas. Educación y diálogo interreligioso, (p. 189-210). Barcelona: Graó).

Estivalèzes, M. (2008). El hecho religioso y la enseñanza laica. La experiencia francesa. Sevilla: Comunicación Social Ediciones y Publicaciones.

Fernández, G., González, H. and Álvarez, J.L. (2014). La educación interreligiosa en el contexto de la educación para la ciudadanía y la cultura de paz: agenda internacional in XIV Congreso Nacional de Educación Comparada / I Congreso Iberoamericano de Educación Comparada. (Madrid: Universidad Autónoma de Madrid, 2014).

García L., Martínez M.J. and Sahuquillo, P. (2012). Hacia una cultura de convivencia. La mediación como herramienta socioeducativa. Cultura y Educación 24(2): 207-217.

García, R. and Martínez M.J. (2016). Inmigración, mediación intercultural y diálogo interreligioso: Lecturas comparadas desde la educación."Revista Española de Educación Comparada, 27, 173-192.

Julian, J. (2000). On religion freedom and civic learning. Intercultural Education, 11(2), 137-144.

Massignon, Bérengère. (2011). "Laïcité in practice: the representations of French teenagers." British Journal of Religious Education, 33(2): 159-172.

The Future of World Religions: Population Growth Projections, 2010-2050. (2017). Pew Research Center's Religion \& Public Life Project. Retrieved 17 July 2017, from http://www.pewforum.org/2015/04/02/religious-projections-2010-2050/

The Global Religious Landscape. (2017). Pew Research Center's Religion \& Public Life Project. Retrieved 17 July 2017, from http://www.pewforum.org/2012/12/18/global-religious-landscape-exec/

Global Christianity - A Report on the Size and Distribution of the World's Christian Population. (2017). Pew Research Center's Religion \& Public Life Project. Retrieved 17 July 2017, from http://www.pewforum.org/2011/12/19/global-christianity-exec/

Religious Hostilities Reach Six-Year High. (2017). Pew Research Center's Religion \& Public Life Project. Retrieved 17 July 2017, from http://www.pewforum.org/2014/01/14/religious-hostilities-reach-six-yearhigh/

Hackett, C., \& Hackett, C. (2017). 5 facts about the Muslim population in Europe. Pew Research Center. Retrieved 17 July 2017, from http://www.pewresearch.org/fact-tank/2016/07/19/5-facts-about-the-muslimpopulation-in-europe/

Santos Rego, M. A. (2017). La educación intercultural y el pluralismo religioso: Propuestas pedagógicas para el diálogo. Educación XX1, 20(1), 17-35.

Sennett, R. (2012). Juntos. Rituales, placeres y política de cooperación. Barcelona: Anagrama.

Tamayo, J. J. 2001. In A. Monclús and C. Saban, (Eds.), Cristianismo: diálogo interreligioso y trabajo por la paz. (p.73-102). Madrid: Síntesis.

Tamayo, J.J. and Fornet-Betancourt, R. (2005). Interculturalidad, diálogo interreligioso y liberación. Estella: Verbo Divino.

Torradeflot, F. (2011). Religiones y pluralismo. Las vías del diálogo interreligioso en España. Madrid: Observatorio del Pluralismo Religioso en España.

2014 Annual Report. (2017). United States Commission on International Religious Freedom. Retrieved 17 July 2017, from http://www.uscirf.gov/reports-briefs/annual-report/2014-annual-report 
Vilà, R. (2015). Hacia el diálogo intercultural e interreligioso: necesidades normativas para una gestión de la diversidad religiosa en el espacio público. Barcelona: Universidad de Barcelona. 